\title{
The Impact of Smartphone Ussage Towards Family Harmony (A Study on Career Women in Makassar City)
}

\author{
Winardi Kamal \\ Departmen of Communication \\ Hasanuddin University \\ Makassar, Indonesia \\ kwinardy@yahoo.com
}

\author{
Tuti Bahfiarti \\ Departmen of Communication \\ Hasanuddin University \\ Makassar, Indonesia \\ tutibahfiarti@unhas.ac.id
}

\begin{abstract}
Smartphones provide positive effect and negative effect if it is not used wisely, including maintaining household harmony for career women. This study aims to determine the impact of smartphone use among career women in their relationships with family, household and how they organize their households from the threat of disharmony during smartphone use. This research was conducted in Makassar, Indonesia by using qualitative research with a case study approach. Data was obtained purposively from observation and indepth interviews from four career women professions (Lecturers, Politicians, Notaries, and Entrepreneurs then analyzed by using the Miles and Huberman model. This study found that there are positive and negative impacts of smartphone use in career women's households, where smartphones can be a solution in communicating when they are far apart, but on the other hand, excessive smartphone use affects each other's intimacy, while the efforts and methods that what career women do to manage the household during a rush of information is to maintain their communication with their husbands and children and to instill an attitude of mutual honesty and trust.
\end{abstract} Family

Keywords-Smartphone, Career Women, Harmony,

\section{INTRODUCTION}

Today, the use of Information and Communication Technology (ICT) has entered into various aspects of people's lives, including the smallest community in society, namely the family. The rapid propagation of information and communication technology will impact the family, be it a positive impact or a negative impact, depending on how the family reacts to it.

The number of innovations and metamorphosis of information and communication technology makes people and families have many choices of products to facilitate all activities and work, including communication. Smartphones are one of the information and communication technology products that are rapidly growing. According to [1] smartphone is a cellular phone with a built-in microprocessor, memory, display, and modem. Smartphones are multimedia phone that combines the functionality of a personal computer and a handset to produce a luxurious gadget, where there are text messages, cameras, music players, videos, games, email access, digital TV, search engines, personal information managers, GPS features, internet, and internet. It can even function as a credit card.

The presence of a smartphone is felt to facilitate communication between family members; apart from having high mobility, it can also be operated easily and effectively. Apart from being a communication device, smartphones can also be used as a means of entertainment and learning in the family. Parents can use smartphones to facilitate their children to play and learn; besides that, smartphones can also be used as a source of entertainment and family conversations. It is not uncommon for family members to find something interesting on the internet, then show it to other family members. It can be used as an exciting conversation material in the household so that it fosters positive interactions within the family.

The discovery and use of smartphones have had an impact on family life, especially in families who have busy schedules outside the home, where husband and wife both have careers and jobs that take up time at their respective work locations, so there is less direct communication, face to face with each other.

The way of interacting between individuals has changed. The past humans interacted verbally face to face; now, along with the massive use of smartphones, they can use features such as video calls that are integrated into the applications on the smartphone in real-time. Moreover, it can provide an accurate display 
of facial expressions when communicating. Besides that, another way used to communicate with smartphones is by using chat applications or communication services with text messages which can also be used to send photos, send voice messages and even make phone calls. According to [2], the main categories of new media include interpersonal communication media, including telephone, smartphone, electronic mail whose content is personal and creates strong relationships.

The existence of the smartphone will facilitate interpersonal communication within the family, both between parents and parents and children, even though they are not in one place. The expected communication is effective and can lead to understanding, pleasure, influence on attitudes, better relationships. Likewise, in the family environment, it is hoped that effective communication between fellow family members will be fostered so that a loving and harmonious relationship will occur.

The dynamics of family life during the advancement of smartphone use is a challenge that must be overcome. Every human being wants a harmonious family, including a career woman who has dual roles in her daily life, namely domestic roles related to household work and roles outside the household that is related to his profession. The career of a career woman has characteristics that require time to achieve progress. Careers require a high level of personal commitment and investment, while household chores are equally important in maintaining family harmony. Even by hiring a housemaid, it does not mean that household problems can be solved just like that because housemaids can only do daily routine work that takes up much time, such as cleaning the house, washing, and so on, while tasks related to childcare and children's education cannot be completely left to domestic helpers [3]. If this does not get special attention in the family of career women, it will cause an imbalance in roles, and if it occurs continuously with strong intensity, it will cause work and family conflicts.

Building family relationships in the digital era is not an easy thing. The failure of a family to respond to the times can lead to an inability to adapt to technological advances, which can be fatal to the damage to the family system itself. The form of the destruction of a family bond as a result of failure to respond to the progress of the times in this digital era, for example, juvenile delinquency, the inability of parents to provide education, loss of free time to play for children, instant and consumptive behavior, incomplete settlement of domestic family problems, family circumstances which are always plagued with problems and discomfort to the issue of husband and wife infidelity. All of this can happen as a result of a family's failure to respond, fortify and adapt in this digital era [4].
This failure can be caused because every family member is caught in the trap of technological advances and advances in information. Every day, every family member is busy in his world with gadgets that are rarely separated from his life. Gadgets have taken over control of almost all of the time and attention of every family member, and if it continues, it will cause household conflicts that result in husband and wife disharmony that can lead to divorce.

Excessive use of gadgets can affect family functions literally, where one aspect that is disturbed is the aspect of social interaction in the family, which includes patterns of communication and social contact [5]. The role of the wife in positioning herself as a career woman (public sphere) and as a housewife (domestic sphere) is crucial to her existence in building or creating harmony in the family [6].

The results of these two studies confirm that both aspects of communication devices and the role of career women have an impact on family harmony. From several previous studies, no one has explained more specifically how career women maintain and organize their family harmony during smartphone use.

Therefore, this research is essential because it will describe and analyze the phenomenon of smartphone use among career women and the impact it has on career women's family harmony. This research was conducted in Makassar City to answer two problem formulations, namely: (1). How is the impact of smartphone use among career women in Makassar City on family relationships in their household? (2). What are the efforts or ways of career women in the city of Makassar to organize their households from the threat of disharmony in the midst of using smartphones?

\section{MethodOLOGY}

In this study, the researcher uses a qualitative research method with a case study approach, where this approach is an empirical knowledge search process to investigate and examine various phenomena in real-life contexts that tend to be vague [7]. In this context, the phenomenon to be studied is the impact of using smartphones for career women in Makassar City on family harmony. Researchers want research results in the form of more complex data details about phenomena that are difficult to express by quantitative methods and do not require statistical data processing. The results of the qualitative research needed by researchers are in-depth information from career women in Makassar City, which are described descriptively.

The location of this research is Makassar City. Makassar City was chosen as the research location based on the consideration that Makassar City is an area with the largest cellular phone users, including smartphones, tablets/computers in South Sulawesi with $85.84 \%$ of users and $66.36 \%$ of Makassar city 
people accessing the internet [8]. There are two types of data obtained in this study, namely primary data and secondary data. Primary data is in the form of direct research, which includes observation and in-depth interviews, while indirect research is in the form of library research.

At the observation stage, the researcher made observations regarding the use of smartphones among women who had worked and were married, then continued with the determination of informants to enter the in-depth interview stage. Observations were carried out by researchers on 15-17 September 2020. Next, at the in-depth interview stage, the researcher interviewed informants who had previously communicated via smartphones to meet and conduct interviews at the agreed time and place. Moreover, the literature study was conducted to find out the concepts, theories, and other relevant research. The literature used in this literature study is in the form of scientific journals, books, and other sources from websites.

This research was conducted using a purposive sampling technique. Purposive sampling is a data collection technique that is carried out intentionally based on predetermined considerations and criteria; the sample is considered to know best about what is expected by the researcher [9]. The criteria specified in the selection of informants are career women who work/career in Makassar City, have a family and have children, are at least 25 years old, and have a smartphone. Based on these criteria, the researchers determined four informants who met the predetermined criteria, namely career women with the professions of Lecturer, Politician, Notary, and Entrepreneur. The selection of these four professions on the grounds can provide an overview of the research conducted.

The data that has been collected is then analyzed interactively, where the process of data collection, data reduction, data interpretation, to concluding is carried out in a dialogical manner to get a natural understanding of research data [10].

\section{RESULTS \& DISCUSSION}

\section{A. The impact of smartphone use among career} women on family relationships

\section{1) The intensity of Communication Through Smartphones}

The rapid penetration of smartphones has also entered the family, and this is judged because the product has become a basic need, especially for families in urban areas. It is undeniable that smartphones with all the sophistication in them can have an impact on one's family life, as in the theory of technological determination, which explains that humans use technology and are surrounded by technology in almost every movement of their lives, including communication technology, McLuhan [11].
Furthermore, [12] explains that technology is an influential part of social life at all levels, including family relationships.

Busy families in urban areas, making communication widely used via smartphones, especially during working hours from morning to evening, even under certain conditions it can be late at night. Due to these conditions, the intensity of communication through smartphones is widely used by career women to interact with their families.

Busy working hours make career women have limited time to communicate directly; however, thanks to advanced technology such as smartphones, they have the freedom to communicate with each other in the family, either with their husbands, children, or with other families. With the support of internet technology, they can even know their current location. The use of social media applications such as WhatsApp, Facebook, Instagram is very helpful for family members to connect.

According to informants, communication via smartphones occurs more often when outside the home or at work. During busy work hours, informants contact their families, asking whereabouts, conditions, and news or sometimes talking about important things that need to be communicated immediately. Communication, in this case, is family communication in the form of delivering messages between family members so that the communication process occurs. The components that must exist in the communication are parents (career women and husbands) and children. These two components can act as both the sender of the message and the recipient of the message, which is followed up with feedback from the message delivered.

The career women informants prioritize communication with their family members. It is inseparable from the importance of maintaining harmonious family relationships with each other. Although communication is done indirectly, the intensity of communication through smartphones is used by career women to avoid miscommunication or misunderstandings in the household.

The intensity of communication through smartphones that occurs in the family proves that communication activities in family life are critical to maintaining and improving harmonious relationships between family members of career women.

This finding shows that the intensity of communicating, which is quite frequent in the family, gives a signal that there is a harmonious and harmonious relationship. There is a sense of belonging and an awareness of the importance of keeping each other informed and also protecting other family members. Although the intensity level between families is not the same, on average, they always communicate and interact, both with immediate or 
nuclear families and those who are far outside the city or island.

\section{2) Social Media Usage}

One of the needs of families to communicate is to use social media applications installed on smartphones. Social media itself is an online media that is used for long-distance communication needs, the process of interaction between users with one another, and getting information through special application devices using the internet network. The purpose of social media is not only as a means of communication to connect users with an extensive area but also as a means of entertainment and education.

Some types of social media that are widely used in families are Facebook, Instagram, Youtube, and WhatsApp. This application is found on various smartphone devices because it is easy to use.

The harmony of a career woman's family, whether with her husband, children, or other families, can be seen from the intensity and quality of her communication. Career women more often use WhatsApp to contact their families, which in fact can also be communicated when family members are at home. Quality communication and not excessive during working hours can increase the closeness of husband and wife as well as with children. Family members feel calm because they feel cared for.

This study shows that the social media applications used by career women are beneficial in all their activities, both those related to their careers or their families. This media is used for the process of interaction and communication without the limitations of space and time. Social media is also helpful as a means to build relationships or relationships and networks that are connected quickly. Social media applications also help the process of finding various sources of information in every area of life. In addition, career women also use social media for entertainment and education for their families.

\section{3) Smartphone Usage Duration and Frequency}

At first, the smartphone was only used as a device for communication, but now it has developed into a device that can almost do everything that supports human activities. In a day, a person can check the smartphone up to many times. Excessive use and habit of checking this smartphone that results in compulsive use even lead to smartphone addiction. Smartphones are objects that are usually seen for the first time in the morning and last seen before going to bed.

Smartphones today can be said to have become a companion to human life in their daily lives, ease of use, and supported by faster connections, making humans unable to separate from their smartphones.

With the ease of using smartphones, many people, including career women, spend 4-8 hours or even more a day using their smartphone devices.

The use of smartphones with a high frequency and duration is also realized by the families of career women that will affect social interactions in the family. Interactions that are usually carried out between parents and their children as a form of nurturing and communication to create family strength will be disrupted. It is because the family is a whole unified system, where if one family member has difficulty interacting directly. It makes the family consciously, or not will reduce or make changes in the pattern of social interaction. The interaction that was initially carried out directly is now starting to be replaced by interaction with smartphones.

Changes in the pattern of social interaction in the family resulted in a more individualistic attitude pattern. Because the change from direct interaction to interaction that is more often done with smartphones has a difference among the emotional roles and social contacts that are not carried out thoroughly. If this happens continuously, it will cause conflict or problems in the family.

Dependence on smartphones is one of the causes of conflict in the family. With the sophistication of smartphones, all access is easily obtained, which can result in abuse of the smartphone.

TABLE I. CAREER WOMEN'S SMARTPHONE USE

\begin{tabular}{|l|l|l|l|l|}
\hline \multicolumn{1}{|c|}{ Research Unit Notary } & \multicolumn{1}{c|}{ Lecture } & \multicolumn{1}{c|}{ Politician } & \multicolumn{1}{c|}{ Entrepreneur } \\
\hline Smartphone Password & \multicolumn{1}{c|}{ Use } \\
\hline Smartphone State (Setting) & Use & Use & Use & Ringing \\
\hline $\begin{array}{l}\text { Freedom to place/check partner's } \\
\text { smartphone }\end{array}$ & Free & Free & Free & Free \\
\hline Use of pseudonyms & Nothing & On Spouse & Nothing & On Spouse \\
\hline Duration and frequency per day & +6 Hours & +5 Hours & +7 Hours & +8 Hours \\
\hline
\end{tabular}

From the table above, it can be concluded that career women have the freedom to place their smartphone or check their partner's smartphone. Most career women's smartphones are ringing, but under certain conditions, for example, in a meeting or meeting, the ringing tone is temporarily silenced. The reason for using passwords on smartphones is to authenticate users and protect smartphone devices, but for each partner to know the password used on the wife's smartphone and vice versa. The use of pseudonyms in smartphones is only used for the names of their respective partners by changing the 
name that is considered the name contains or symbolizes love and affection. The duration and frequency of using smartphones in a day are reasonably high. It is because the activities and busyness of career women in working hours require smartphone devices to support their activities and communicate with their families.

\section{B. Efforts and ways of career women in Makassar City to organize their households from the threat of disharmony during smartphone use}

Efforts to achieve harmony and harmony in domestic life are an absolute thing that families must do in this era. Technology is a form of modern life, where everyone from small children to the elderly can access everything through their smartphone. Families are now required to adapt to technological advances that are increasingly developing and affecting the lives of each family member structurally and culturally.

Married life always has dynamics in the form of problems and challenges one after another. It can even be said, family life is never devoid of problems and challenges, both from within and from outside. Several things in the family are identified as risk factors that can create problems and challenges, thus creating vulnerability in the family. These risk factors differ from one family to another.

[13] mentions six risk factors: poverty, unemployment, divorce, death, chronic disease, and reproductive infertility. Meanwhile, [14] added the factors of technological, social, cultural, and political development as a source of collective stress that directly affects family life and conditions.

The majority of career women still believe that the key to a harmonious family is to feel close and maintain their communication with their husbands and children. Virginia Satir [15] argues that communication is vital in maintaining harmonious relationships among all family members. To survive depends on how they communicate. The satire describes the communication process as "A giant umbrella that protects and influences everything that happens between people. Everyone is involved in communication, both verbal and non-verbal, at every step of their lives. Good communication is not just an exchange of words between people. It is more than that. Good communication is about what we say, how we say it, and when or in what context we say it. Good communication is communication that is delivered, openly, and honestly. This kind of communication is congruent communication.

From the research data, it was found that the way career women organize their households from the threat of disharmony during smartphone use is by busy career women outside the home, as much as possible when they are at home it can be maximized by interacting with family members, especially husbands and children (Family time), doing something with the family, such as telling stories to each other, is far more valuable than everyone busy with their respective smartphones.

Being honest with one's partner is also an attitude that career women must maintain. With the presence of smartphones, it is indeed difficult to let go at this time. Smartphones can be said to have become a primary need, negative influences that can arise such as suspicion and lack of trust between husband and wife because they pay more attention to their smartphones, this can lead to misunderstandings between the two, but the key is communication and mutual openness among partners. Smartphones are not a place to hide secrets, couples have the freedom to hold each other's smartphones, and nothing is disguised, even though they have trusted each other.

The study [15] concluded that what is needed to build family harmony through communication is an attitude of empathy and a sense of equality in each family member. These two things will make a person a leveler who does not feel superior or inferior in front of others. Thus, when communicating, both parties will be able to freely and openly express their respective desires and be ready to slightly lower each other's demands to create win-win communication that leads to a win-win solution or win-win agreement.

The process of forming relationships in one household requires a willingness to build harmonization in the family; building intense communication with husbands, children, including inlaws, is a way for career women to maintain the integrity of their household, at least even though they are busy and outside the home. Career continues to contact his family to ask about lunchtime and where his family is. It aims to keep each other and know the news of each family member so that this can help strengthen family relationships with each other.

With the availability of communication facilities such as smartphones, families need a communication strategy when interacting with family (family time).

As for tips for overcoming the excessive use of smartphones, career women and husbands can invite their children to make rules and agreements together and try to live them together. For example, there should be no smartphones when eating together or during joint recreation. The use of smartphones, especially in children, is limited in duration of use.

Smartphones can be used more wisely by prioritizing a direct and real presence who always listens and talks heart to heart with loved ones. 
TABLE II. ASPECTS OF FAMILY HARMONY

\begin{tabular}{|l|l|l|l|l|}
\hline \multicolumn{1}{|c|}{ Aspects } & \multicolumn{1}{c|}{ Notary } & \multicolumn{1}{c|}{ Lecture } & \multicolumn{1}{c|}{ Politician } & \multicolumn{1}{c|}{ Entrepreneur } \\
\hline Family interaction & Open communication & Open communication & Open communication & Open communication \\
\hline Quality time together & Have intimate time & Have intimate time & Have intimate time & Have intimate time \\
\hline Cooperation & $\begin{array}{l}\text { Help \& Support Each } \\
\text { Other }\end{array}$ & $\begin{array}{l}\text { Help \& Support Each } \\
\text { Other }\end{array}$ & $\begin{array}{l}\text { Help \& Support Each } \\
\text { Other }\end{array}$ & $\begin{array}{l}\text { Help \& Support Each } \\
\text { Other }\end{array}$ \\
\hline
\end{tabular}

From the table above, in establishing and maintaining relationships, the profession of career women always prioritizes communication. At the beginning of the day, before each activity, the informant always took the time to chat casually with his partner. For example, at breakfast, interaction with children was also done by taking care of their needs, including school. Every career woman profession has time together or quality time with family minimizes the use of smartphones, takes advantage of short times before going to bed and on vacation or just eating together outside the home are activities that are usually done to strengthen relationships with each other. In terms of cooperation, career women and their partners help and support each other, work together, guide and direct children's learning.

\section{CONCLUSION}

Using smartphones in maintaining family harmony is something that one's should take care seriously to avoid family failure. It is very obvious from the results of this study which found that smartphones for career women in family relationships have a positive and negative impact. It provides convenience and smooth communication in their daily lives when they are far away, even though the ease of communication does not necessarily continue when they are at home or in the same place. While the negative impact caused is that smartphones with various advanced features and applications contained in them make career women. It includes their family members, tends to play smartphones for a long time, namely with a duration and frequency of more than 4 hours which is included in the high category, where this is if done continuously for a long time, will cause psychological effects, health including the effects of social interaction in the family.

Furthermore, the efforts and ways in which career women manage the household in the midst of using smartphones from the threat of disharmony, by maintaining communication as much as possible while at home can be maximized by interacting with family members, especially husbands and children (quality time). To overcome the excessive use of smartphones, in the future career women and husbands can invite their family members to commit to using smartphones wisely and proportionally so as not to affect social interactions in the family.

So, it is extremely important to look after family harmony by considering the positive and negative effects that smartphones might carry also to know how to use them to protect the family's well-being is considered vital to comprehend.

\section{REFERENCES}

[1] S. C. Williams, B.K. and Sawyer, Using Information Technology: A Practical Introduction to Computers \& Communications, 9th ed. New York: New York. McGrawHill, 2011.

[2] D. McQuail, Teori Komunikasi Massa, 6th ed. Jakarta: Salemba Humanika, 2011

[3] Supriyantini, "Hubungan Antara Pandangan Peran Gender dengan Keterlibatan Suami dalam Kegiatan Rumah Tangga," Universitas Sumatera Utara, 2002.

[4] F. F. Saputro, "Membangun Keluarga Digital Di Era Industri 4.0 (Bagian 1)." Pustaka Bergerak, 2019.

[5] I. Lestari, A. W. Riana, and B. M. Taftazani. "Pengaruh gadget pada interaksi sosial dalam keluarga." Prosiding Penelitian Dan Pengabdian Kepada Masyarakat 2.2 (2015).

[6] L. Faridha, "Eksistensi Wanita Karir dalam Keharmonisan Keluarga: Studi Kasus Guru Madrasah Aliyah Ali Maksum Yogyakarta,” 2018.

[7] R. K. Yin, Studi Kasus: Desain dan Metode. Jakarta: Rajawali Pers, 2015.

[8] BPS Kota Makassar, "Statistik Kesejahteraan Rakyat Kota Makassar 2019." Badan Pusat Statistik Kota Makassar, Makassar, 2019.

[9] Sugiyono, Metode Penelitian Kuantitatif, Kualitatif, $R \& D$. Bandung: Alfabeta, 2012.

[10] J. Milles, M. B., Huberman, M. A., \& Saldana, Qualitative Data Analysis A method Sourcebook (Terjemahan Tjetjep Rohindi Rohidi)., 3rd ed. Sage Publications, Inc., 2014.

[11] Morissan, Teori Komunikasi: Individu Hingga Massa. Jakarta: Prenadamedia Group, 2013.

[12] C. Thurlow, L. Lengel, and A. Tomic. Computer-mediated communication. Sage, 2004.

[13] K. Ariel, Family resilience and good child outcomes. Wellington: Ministry of social development, 2003.

[14] Eldridge, Eucalypt Domestication and Breeding. Claredon Press, 1994.

[15] Asyhabuddin, "Harmonisasi Keluarga Melalui Komunikasi Setara: Model Terapi Keluarga Virginia Satir," Komunika J. Dakwah Komun., vol. Vol.6 No.1, 2012. 